matter was discussed by a committee of inquiry appointed by the Department of Scientific and Industrial Research. The latest of the testing stations built abroad is that at Vitry-sur-Seine, near Paris. A description of this station appeared in Engineering of August 4, 1933, and it was the subject of special notice in Mr. H. N. Gresley's presidential address to the Institution of Locomotive Engineers delivered on September 27, in which he made a vigorous plea for a similar plant in England. Of the usefulness of such a station, he said, there can be no doubt. The requirements of the export trade in locomotives and the conditions of railway transport at the present day indicate the need for better facilities for the scientific study of the locomotive than are generally available in Great Britain in order that improvements in design, resulting in a higher standard of thermal efficiency and economies in fuel consumption, might be effected. Mr. Gresley described the station at Vitry as the most perfectly equipped in the world. The plant is designed to test locomotives having an axle load up to 30 tons running at all speeds up to 100 miles per hour. The hydraulic brakes for the testing bench, which were made by Messrs. Heenan and Froude, Worcester, can absorb up to 7,200 horsepower. The total cost of the station was $£ 120,000$. Mr. Gresley advocated a similar station for Great Britain, to be financed by Government, which might set up an organisation under the Department of Scientifie and Industrial Research for its control, with power to levy fees for its use.

\section{Photoelectricity in the Theatre and on the Road}

A PAPER read by Dr. N. R. Campbell and Mr. C. C. Paterson to Section A (Physical and Mathematical Sciences) of the British Association meeting at Aberdeen on September 11 described the vicissitudes of the photoelectric cell during the sixty years since it was invented. The development of the cells was almost complete forty years ago, but, with the exception of a few men of science, no one took much interest in them until ten years ago. Apparently photoelectricity had arrived before the world was ready for it. The invention of the sound film created a great demand for photoelectric cells. Formerly, they were made in ones and twos by laboratory workers. Now they are demanded in thousands, and it is well worth the while of large industrial firms to manufacture them and develop them further. The obstacle to their extension that had to be overcome was, not lack of technical power, but simply ignorance on the part of those that might use them. Engineers had not yet recognised the many important purposes to which they could be put. The great rapidity of their action made them most useful for timing races. If a speed limit were imposed by the new Traffic Act, photoelectric cells could be used to make it effective. There is no difficulty in timing a car over 15-20 feet without any possibility of human error.

\section{Classification of Stone Age Cultures}

WE have received a communication from Messrs. J. Reid Moir and J. P. T. Burchell in which they criticise the methods of classification adopted in the arrangement of the special exhibit, now on view at the British Museum, illustrating the cultures of the Old Stone Age. The system, which, in their opinion, clearly has a geological basis, in the main is that recently put forward by Dr. L. S. B. Leakey, and the points to which criticism are directed relate to the differentiation and arrangement of the earlier stages of that schematisation. The writers maintain that the tripartite division of the sub-crag implements, one division being named 'Icenian', a name suggested by Sir E. Ray Lankester for the whole group of precrag artefacts, has no relation to the facts as disclosed by' recent investigation, but not yet published. Further, exception is taken to the equation of 'evolved Clactonian' (that is, High Lodge) with implements of Lower-Middle Acheulean antiquity, when the latter are demonstrably, on geological evidence, prior in date ; while it is pointed out that no mention is made of recent work showing that Coombe Rock was immediately followed by the Middle Mousterian cultures of Crayford and Northfleet. Again, it is said, certain specimens from below the sand of unknown origin at Ivry Street, Ipswich, are erroneously labelled "flakes from the English Brown Boulder Clay". More generally, the whole classification of the earlier cultures into 'hand-axe' and 'flake' industries is regarded as invalid, as here in Great Britain, at least, these often occur on undisturbed floors in intimate association and are beyond doubt contemporaneous. Moreover, it is common knowledge that large numbers of hand-axes are themselves made from flakes.

Messrs. ReId Morr and Burchell pay a welldeserved tribute to the character of the exhibit, for which they credit the chief responsibility to Dr. Leakey. This special exhibit of stone age cultures, however, is intended to bring before the public new views and to stimulate discussion; and although Dr. Leakey helped to prepare a scheme of classification of stone age cultures for submission to the recent International Congress of Anthropological and Ethnological Sciences, his views are not all peculiar to himself. It must also be pointed out that while the writers' main criticisms of the classification attempted have a chronological basis, the principle of classification is cultural. The chronological relation of members in two parallel, but independent, developmental series is irrelevant for this purpose, even though specific types equated as occupying analogous positions in the series can be shown to be, and admittedly are, widely separated in chronological succession. On the other hand, the criticism of the distinction drawn between the 'hand-axe' and 'flake' industries on the ground of their intimate association and contemporaneity argues neither for nor against. the validity of the interesting hypothesis of two cultures of independent origin and lines of development; but neither does it preclude its possibility. In default of published evidence, the weaknesses of the tripartite division of the pre-crag industries have still to be demonstrated; but Mr. Reid Moir himself has argued on several occasions for the cultural 
differentiation of these implements, and from this has inferred a difference in racial origin.

\section{The Cable Repair Ship H.M.T.S. Monarch}

IN connexion with 'Telephone Week' (October 1-6), members of the general public had an opportunity of inspecting the Post Office cable repair ship Monarch, which was lying in the Thames off the Tower. This ship is fitted out with the special gear necessary for carrying out all the operations required in cable laying and repair, on which service she is at sea for most of the year attending to cables such as those laid between Great Britain and the Continent. The positions of cables are charted so that a faulty section or broken cable may be located and raised by means of grappling gear, of which there are various types provided. The ship's testing laboratory contains apparatus for the measurement of conductor resistance, insulation resistance, localisation of faults and other tests applied to the end of a cable which has been hauled on board. Sections of defective cables are replaced by lengths of new cable, a supply of which is carried in the ship, and the repaired cable relaid and charted, a somewhat noticeable feature of the cross Channel cables being the large number of repairs marked on the charts. The ship is provided with wireless equipment including a valve transmitter and, in reserve, a quenched-spark transmitter. In addition to an ordinary receiver there are a directional receiver and an emergency automatic call whioh rings an alarm bell, when the operator is not on watch, as soon as it responds to three 'Iongs', of four seconds duration, out of the twelve sent for the S O S signal. The chart house contains an echo sounding device. The ship's complement is 14 officers and 50 ratings, this large number being required on account of the technical duties, in addition to ordinary duties, carried out on board.

\section{Telephone Statistics of the World}

IN Electrical Communication of July the telephone and telegraph statistics of the world have been published up to January 1933. The United States have now 53 per cent of the total number of telephones in use in the world, Canada has 4 per cent, Germany 9 per cent, Great Britain $6 \cdot 5$ per cent, France 4 per cent, the remaining European countries 14 per cent and all other countries 9 per cent. In January 1928, the United States had 60 per. cent and Europe 28 per cent as compared with 33.5 per cent now. Whilst the number of telephones in Europe has increased by about 20 per cent during those five years, the number in the United States has diminished by 12 per cent. San Francisco leads the world with $36 \cdot 5$ telephones per 100 of the population and Washington comes next with $33 \cdot 3$. Stockholm is third with 31.8. In Canada, Toronto has $25 \cdot 6$ and Vancouver 28.1. Paris has 15, Berlin $11 \cdot 1$ and Munich 10. London heads the cities in Great Britain with 8.8 and Edinburgh comes next with 6.9. Honolulu, with a population of 138,000 , has $11 \cdot 7$ telephones per 100. Whilst the United States have 70 miles of telephone wire per 100 of the population, Canada has 48, Australia and New Zealand 39, Sweden has
$32 \cdot 7$ and Denmark $31 \cdot 5$. Germany has $23 \cdot 2$, Great Britain and Northern Ireland $22 \cdot 6$ and France $10 \cdot 7$. India and China have only 0.11 miles of telephone wire per 100 of the population. Czechoslovakia, the United States and New Zealand use their telephones more than other countries. The telephone conversations per capita in these three countries in 1932 were $224 \cdot 5,204 \cdot 6$ and $205 \cdot 8$ respectively. This compares with 33 in Britain and Germany and 20.5 in France. The number of conversations by telephone now averages about 100 times as many as of communications sent by telegraph.

\section{Social Sciences in the United States}

THE social sciences and, especially, applied social science or civics, figure prominently in discussions of current educational policies in the United States, as witness the monthly Educational Review published as a supplement to School and Society of July 7. An advanced school of thought has lately found an exponent in Richard Welling, whose "Civics as it should be taught" has provoked discussion about the courage needed by teachers to teach "the real facts about distorted democracy", and led to a proposal to form a union to teach civic truth and to protect anyone who does it. A new monthly journal of educational criticism and reconstruction is to appear this month under the name of the Social Frontier (2 dollars annually, 66 West 88th Street, New York) to be devoted to "serving the emerging consciousness among American teachers that they must participate fully in social processes reshaping the American order". The report of the American Historical Association's commission on the social studies has, after repeated revisions, reached its final form, a compromise between conflicting views (New York: Charles Scribner's Sons. 170 pp., 1.25 dollars). It calls for increased emphasis on social instruction from the kindergarten upward and extending to the adult population, and it stresses the need for a more realistic approach with frequent interpolation of the question: How is it in your own town, city, country? The principal article in the same issue, entitled "Cultural Objectives of Health Education" by the professor of public health, Yale School of Medicine, urges that teachers should bear in mind that they are educating citizens and not merely doctors or lawyers or farmers, or stenographers or salesmen or bank presidents.

\section{Research in Industrial Health}

THE fourteenth annual report of the Industrial Health Research Board up to June 30 emphasises, as have previous reports, that, "the study of the physiology and psychology of the worker is to reveal as many problems as are solved : to the fundamental problems becomes added that of overcoming difficulties in methods of approach and in technique". Trustworthy data about the incidence and kind of ill-health from which the workers in different occupa. tions suffer are a pressing need. In the introduction to the report is a discussion of some of the difficulties in the way of obtaining data. An account of the chief problems now being investigated is given in outline. 